\title{
Interactive comment on "Spatial Seismic Hazard Variation and Adaptive Sampling of Portfolio Location Uncertainty in Probabilistic Seismic Risk Analysis” by Christoph Scheingraber and Martin Käser
}

Christoph Scheingraber and Martin Käser

scheingraber@geophysik.uni-muenchen.de

Received and published: 20 December 2019

Thank you for this comment.

We understand that it can be hard to follow the technical details of a highly specialized paper such as this one, in which due to the format we can only provide a concise description of the general methodology of seismic hazard and risk assessment. While we believe that it would clearly be out of scope to explain all details of this scientific

Printer-friendly version

Discussion paper area, in our updated manuscript we provide some textbook suggestion for further study 
for the interested reader at the end of Section 2.1:

Page 3, Section 2.1 Probabilistic Seismic Hazard and Risk Analysis, Lines 18: "For NHESSD more details on PSHA and PSRA, we refer to the comprehensive textbook of McGuire (2004)."

In addition, Section 3.1 has been almost entirely rewritten to elaborate more on the

Interactive

comment utilized hazard model.

Interactive comment on Nat. Hazards Earth Syst. Sci. Discuss., https://doi.org/10.5194/nhess2019-110, 2019. 